\title{
卒前教育に求められる リハビリテーション医学
}

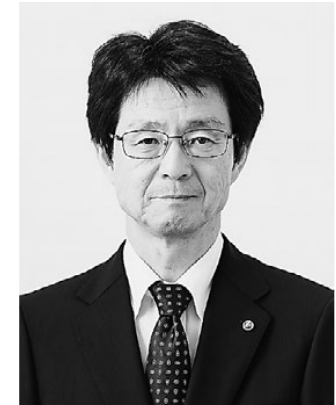

大学医学部における卒前教育では,「多様なニー ズに対応できる医師の養成」を目標に掲げ，最低 限カバーすべき教育項目としてモデル・コア・カリ キュラムが示されている.リハビリテーション医学 については, 概念と適応, 国際生活機能分類, 福 祉・介護との連携, リハビリテーション・チームの 構成とその中での医師の役割を説明できること, 機能障害と ADL の評価ができること, 理学・作業・ 言語聴覚療法および歩行補助具, 車椅子, 義肢 · 装具を概説できること，が学修目標として提示さ れている.ささらに, 疾患レベルで, 脳血管障害の急 性期・回復期・生活期のリハビリテーション, 運動 器疾患, 心大血管疾患, 呼吸器疾患, 脳性麻瘴, 廃用症候群および高齢者に対するリハビリテー ションを説明できることが加わる，卒前教育にお いて, これだけの範囲を網羅した講義ならびに臨 床実習を構成するには，相応の履修時間と教育ス タッフが必要になる.

関西医科大学での卒前教育を自己分析すると, 臓器別系統講義として 5 日間計 20 コマのリハビリ テーション医学の講義を行っており, 知識を学生に 教育する座学の機会には恵まれている，また，平 成 30 （2018）年にリハビリテーション医学講座と なってから, 全学生に対するクリニカル・クラーク シップが 3 日間から 1 週間となり, 学修目標として 掲げられる各疾患のリハビリテーション評価を実 習グループ単位で経験させることがある程度可能 になった．生活期に関してもデイケア実習を 1 日
設けており,また，選択制での 2 週間の臨床実習で は, 回復期病棟実習や電気診断, 講演形式での症 例発表を指導している. 教員数が少ないために負 担感はあるものの, モデル・コア・カリキュラムの 学修目標に近づいてきたという感触は得ている. 「多様なニーズ」として掲げられている「チーム医 療, 地域包括ケアシステム, 健康長寿社会へ対応 できる実践的臨床能力の育成」をめざしたカリキュ ラムとして, 活動再建を最適化するリハビリテー ション医療の思考過程は重要であり, その機会を 臨床実習の中で体験させ, 自己学修を促すような 環境や課題を模索していくことが, リハビリテー ション医学の卒前教育にかかわる教員の重要な使 命となる.

一方で, 医師国家試験出題基準には，「医師とし て医療現場で第一歩を踏み出す際に少なくとも具 備すべき基本的知識・技能・態度」すなわちコンピ テンシーが具体的に提示されており, 共用試験 CBT の標準化とリンクして臨床能力を問う問題が 重視されてきている．医師としての国家資格を得 るための試験であることから, その出題内容は学 修成果基盤型教育 (outcome-based education) に おける目標として全国にメッセージを発信する力 を有する. 出題基準改訂に向けた医師国家試験改 善検討部会による報告書においても, リハビリテー ション医療の重要性が提唱されており, 活動再建 に必要な思考過程の学修を促すような医師国家試 験問題を増やしていく取り組みが求められる. 